AESCHINES 
THE ORATORY OF CLASSICAL GREECE

Translated with Notes - Michael Gagarin, Series Editor

VOLUME 3 


\section{A ESCHINES}

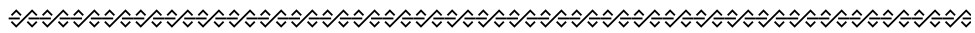

Translated by Chris Carey

$\checkmark$ UnIVERsity of TEXAs PRESS, AUSTIN 
Publication of this book has been generously assisted by grants from the National Endowment for the Humanities and the Gladys Krieble Delmas Foundation.

Copyright (C) 2000 by the University of Texas Press All rights reserved

Printed in the United States of America

First edition, 2000

Requests for permission to reproduce material from this work should be sent to Permissions, University of Texas Press, Box 7819, Austin, TX 78713-7819.

(2) The paper used in this book meets the minimum requirements of ANSI/NISO Z39.48-I992 (RI997)

(Permanence of Paper).

Library of Congress Cataloging-in-Publication Data

ISBN 0-292-7I222-7

ISBN 0-292-7I223-5

Aeschines.

[Works. English. 200o]

Aeschines / translated by Chris Carey. — Ist ed.

p. cm. - (The oratory of classical Greece ; v. 3)

Includes bibliographical references (p. ) and index.

ISBN 0-292-7I222-7 (alk. paper) — ISBN 0-292-7I223-5 (pbk. : alk. paper)

I. Aeschines - Translations into English. 2. Speeches, addresses, etc., Greek-Translations into English. I. Carey, Christopher.

II. Title. III. Series.

PA3823.A36 2000

$885^{\prime}$.OI-dc2I

00-008419 
In Memory Of My Sister, Pauline Carey/Reffould I954-I997 
THIS PAGE INTENTIONALLY LEFT BLANK 